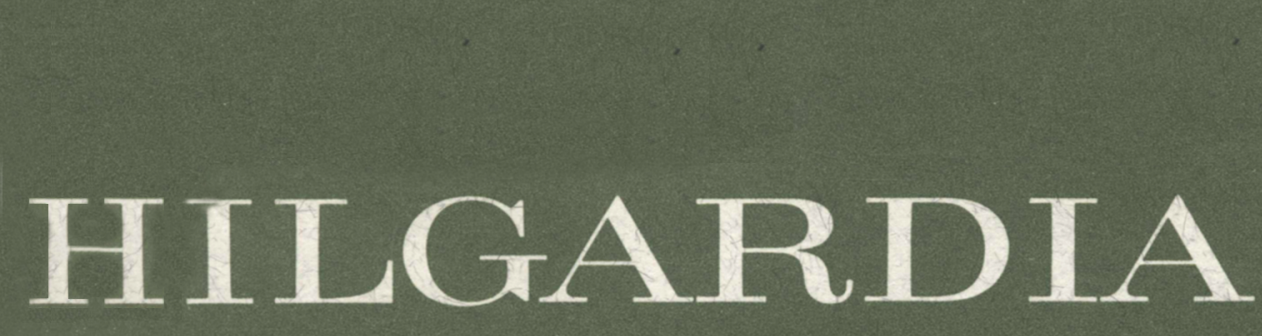

A JOURNAL OF AGRICULTURAL SCIENCE PUBLISHED BY THECALIFORNIA AGRICULTURAL EXPERIMENT STATION

Volume $50 \cdot$ Number $5 \cdot$ September, 1982

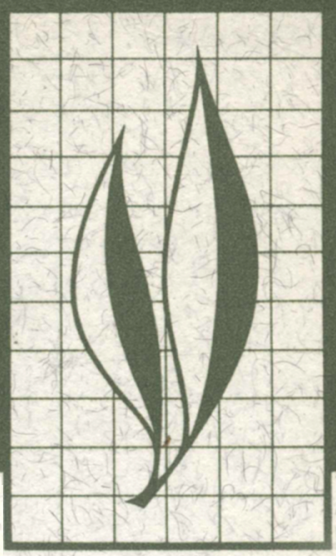

\title{
Observations on the Biology of
} Cinara ponderosae (Williams) (Homoptera:Aphididae) in the Westside Forests of the Sierra Nevada

D. J. Voegtlin and D. L. Dahlsten 


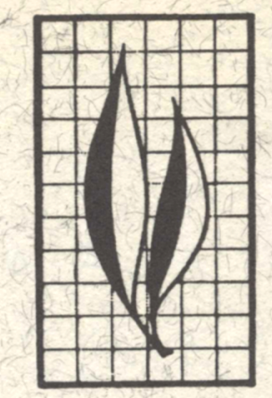

Observations on the biology and population dynamics of Cinara ponderosae Williams) in the westside Sierra Nevada forests of California are presented.

The species is believed to be anholocyclic, because sexuales, eggs, and fundatrices were absent. In the spring following winter survival on ponderosa pine (Pinus ponderosa Lawson) in the foothills, populations migrated up the west slope of the Sierra Nevada. The local population in Blodgett Forest, Eldorado County, began in May with the number of aphids and colonies expanding throughout June and collapsing by the end of July. Detailed study of instar distribution, based on a sampling every four days, showed a gradual increase in older instars until population collapse. First generation 4th instars and apterae moved throughout the tree and began new colonies.

Predators, primary and secondary parasites, and ant associates were noted and discussed.

\section{THE AUTHORS:}

David J. Voegtlin, formerly graduate student, Department of Entomological Sciences, Division of Biological Control, University of California, Berkeley, is with the Illinois Natural History Survey, Section of Faunistic Surveys and Insect Identification, $607 \mathrm{E}$. Peabody, Champaign, IL 61820.

Donald L. Dahlsten is Professor of Entomology, Division of Biological Control, and Entomologist in the Experiment Station, University of California, Berkeley. 


\section{J. Voegtlin and D. L. Dablsten}

\section{Observations on the Biology of Cinara ponderosae (Williams) in the Westside Forests of the Sierra Nevada ${ }^{1}{ }^{2}$}

\section{INTRODUCTION}

PALMER (1926) STUDIED the life histories of several species of cinarans (Cinara) in Colorado, and Johnson (1965) looked at the effect of heavy infestations of $C$. pseudotaxifoliae Palmer on Douglas-fir seedlings. Otherwise, few studies have been made of the 125 or more species of cinarans named or collected west of the Rocky Mountains in the United States and Canada.

In 1972, we found Cinara ponderosae (Williams) to be the most abundant cinaran of the mid-elevation westside Sierra Nevada forests. The aphid was noted only on small specimens ( $3 \mathrm{~m}$ tall or less) of Pinus ponderosa Lawson and P. jeffreyi Grev and Balf., although trees of all sizes were examined throughout the study. A study of $C$. ponderosae was undertaken from 1973 to 1975 in conjunction with taxonomic and biological studies of other Cinara spp. found in this region. Aphids in this genus are potentially important as pests in nurseries and tree plantations.

\section{METHODS}

\section{Study area}

Blodgett Experimental Forest, located $16 \mathrm{~km}$ northeast of Georgetown, El Dorado County, California, in the central Sierra Nevada (Fig. 1) was used for most of the summer observations. The forest is a mixed conifer, predominantly second-growth stand of six principal tree species: ponderosa pine, Pinus ponderosa; white fir, Abies concolor (Gordon and Glendenning) Lindley; incense cedar, Calocedrus decurrens (Torrey) Florin; sugar pine, Pinus lambertiana Douglas; Douglas-fir, Pseudotsuga menziesii (Mirbel) Franco; and California black oak, Quercus kellogii Newberry.

Two sites were chosen for sampling in 1974 and for distributional analysis in 1975 . One was at the south end of the experimental forest on the southeast slope of Sand Mountain; the other was $3 \mathrm{~km}$ east of the forest in the vicinity of Stumpy Meadows Lake. Both sites were characterized by abundant ponderosa pine regeneration.

\section{Sampling, 1974}

Ponderosa pines were examined at each site until a branch with a colony was found, placed in a plastic bag, and taken to the laboratory for study. Ten colonies were collected at each site; collections were made every 4 days. Only one colony per tree was taken. In

1 This paper is part of a thesis submitted in partial fulfillment of the Ph.D. degree, University of California, Berkeley, by the senior author (DJV), March, 1976. 


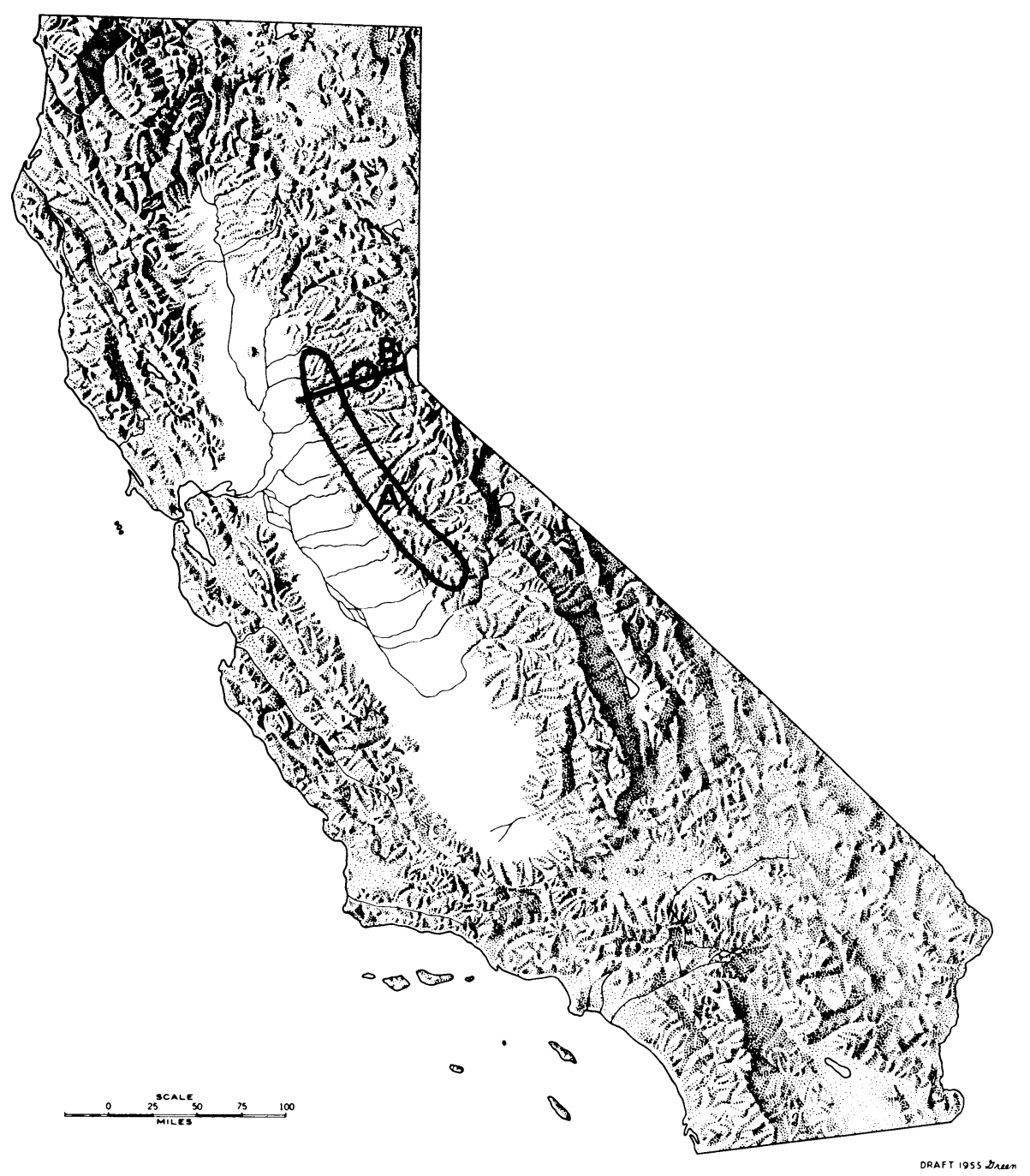

Fig. 1. Topographical map of California. Area A indicates foothill region where C. ponderosae was collected during the winter. Line $\mathrm{B}$ is the approximate location of the elevational transect run in 1975; open circle on line B is Blodgett Experimental Forest.

the laboratory, all aphids, predators, ants, parasites, and mummies were removed. Ants, adult predators, and 1st and 2nd instar aphids were placed in alcohol. Third and 4th instar and adult aphids were put in small petri dishes to await mummification. After 4 to 7 days aphids that had not mummified were pooled with the 1 st and 2 nd instars. Mummies were placed in gelatin capsules to rear parasitoids. Larval predators were put into gelatin capsules (000) or small petri dishes and fed aphids until mature. The number of each instar, alatoid or apterous 3rd and 4th instar nymphs, alate or apterous adults, associated insects, and mummies were recorded for each sample.

In addition to and concurrent with the samples taken for the laboratory, 25 colonies, each on small $(<1.5 \mathrm{~m}$ ) separate trees, were marked and examined in situ every fourth day. Thus, each tree could be examined thoroughly, and counts, including associated insects, could be recorded without excessively disturbing the aphids. 


\section{Life-table construction}

Time-specific life tables were constructed using Hughes's $(1962,1972)$ technique to predict the parameters of an equivalent sample taken one instar period later. One instar period was taken as the approximate time needed for complete development and moult for any of the first three instars, providing the temperature was above the minimum threshold for development. Life tables assumed a stable instar distribution in the population at the time of sampling. A stable instar distribution occurs if the rate of reproduction remains relatively constant for a time period. The following formula (Hughes 1972) was used to calculate the numbers in the first three instars (I, II, III) expected in a geometric progression based on the number of the first three instars observed in the samples taken.

$$
\mathrm{e}=\frac{\mathrm{I}+\mathrm{II}}{\mathrm{II}+\mathrm{III}}=\text { potential rate of increase }
$$

Expected number of aphids in

$$
\begin{aligned}
\text { III: } & \mathrm{T}_{1}=\frac{(\mathrm{I}+\mathrm{II}+\mathrm{III}) \mathrm{e}^{\lambda}-1}{\left(\mathrm{e}^{\lambda}\right)^{3}-1} \\
\text { II: } & \mathrm{T}_{2}=\mathrm{e}^{\lambda} \mathrm{T}_{1} \\
\text { I: } & \mathrm{T}_{3}=\left(\mathrm{e}^{\lambda}\right)^{2} \mathrm{~T}_{1}
\end{aligned}
$$

The number of aphids represented by the geometric progression was then compared with the observed using a $\mathrm{X}_{1}^{2} \mathrm{df}$ analysis. Values greater than $3.84(\mathrm{p}=0.05)$ were assumed to be evidence that a stable instar distribution did not exist. Data from both sample sites were combined, and each life table was based on a sample of 20 colonies.

Losses due to parasitism was estimated by the number of mummies formed in the laboratory following collection. Losses due to predators were based on the number of aphids of various instars necessary to rear the various predator larvae, collected with the sample, to maturity. Losses due to Deraeocoris ingens were estimated. It was assumed that all alatoid 4th instars moulted and emigrated before the next sampling data.

\section{Distributional sampling, 1975}

Resource utilization and movement of $C$. ponderosae within the host tree were measured. Fifty ponderosa pines, small enough to examine thoroughly, were marked in each of the two study areas for weekly sampling during 1974 beginning May 11. Trees with aphids on them were mapped, and colonies, aphid forms, ants, predators, and parasites were located (Fig. 7 and 8). Trees were drawn as if sectioned at each internode from bottom to top, each circle (whorl) representing the trunk and each line from it, one branch. Colony locations were designated by solid circles, and aphid morphs, ants, and associated insects were coded for each colony location. Observations continued until C. ponderosae was found on only one of the 100 marked trees. 


\section{RESULTS}

\section{Anholocycly in C. ponderosae}

During the spring and early summer of 1973, many colonies of $C$. ponderosae were composed of a single alate viviparae and immatures. These were assumed to be at least second generation, because fundatrices are all apterous. In the early spring of 1974 , a thorough search was made for eggs, but none could be found. All colonies, when finally observed, were started by alate viviparae. Specific colonies were then followed throughout the summer, fall, and into the winter; no sexuales were found.

Climate at the altitude $(1,000$ to $2,000 \mathrm{~m})$ of this region of the Sierra Nevada is too severe during the winter months for aphid survival. Heavy snow, freezing temperatures, and winter storms are climatic factors. In light of this, plus the absence of sexuales, eggs, and fundatrices, a source of the spring alatae had to be found. Searches along the foothills (200 to $300 \mathrm{~m}$ elevation) during the winter of 1974-75 produced many collections of $C$. ponderosae (Fig. 1). Also, a United States Forest Service nursery at Placerville (located in the foothills of the Sierra Nevada) had a $C$. ponderosae buildup on its small ponderosa pines almost every winter.

In the spring of 1975 a west-to-east elevational transect was run at weekly intervals (Fig. 1). Colonization of ponderosa pine by $C$. ponderosae was observed to move from low to high elevations; this closely matched bud burst in small pines. At this time of the year, prevailing winds from the west may have helped this migratory pattern.

These observations led us to consider $C$. ponderosae to be anholocyclic in this area of the Sierra Nevada.

\section{Instar age distribution of $C$. ponderosae}

The 39 instar distributions from sampling in 1974 (Fig. 2) were analyzed for fit to a geometric progression. Twenty-seven, or 67 percent, had $\mathrm{X}^{2} 1 \mathrm{df}$ values low enough for a geometric progression to be assumed (Tables 1,2 ). The validity of assuming stable instar age distributions in the sets of data that approximate a geometric pattern has been questioned by Carter, Aikman, and Dixon (1978). They calculated a chi-square heterogeneity test using Hughes's data from 1960 and 1961 and found that, although individual sets of instar distributions reflect a geometric progression, the sum of the $\mathrm{X}^{2}$ values strongly suggests that the sets of samples are not from a homogeneous population with respect to instar distribution. Table 3 is a similar test that utilized the data given in Tables 1 and 2. Results were similar to those found by Carter, Aikman, and Dixon (1978): that the heterogeneity test suggests that all of the samples were not from a homogeneous population with relation to instar age distribution.

Figure 2 shows that the alatoid 3rds and 4ths fluctuated considerably between sampling dates. Population of $3 \mathrm{rd}$ and older instars increased up to mid-June and peaked two weeks after colony size peaked (Fig. 3) but corresponded closely to the peak number of colonies in 1975 (Fig. 4). 


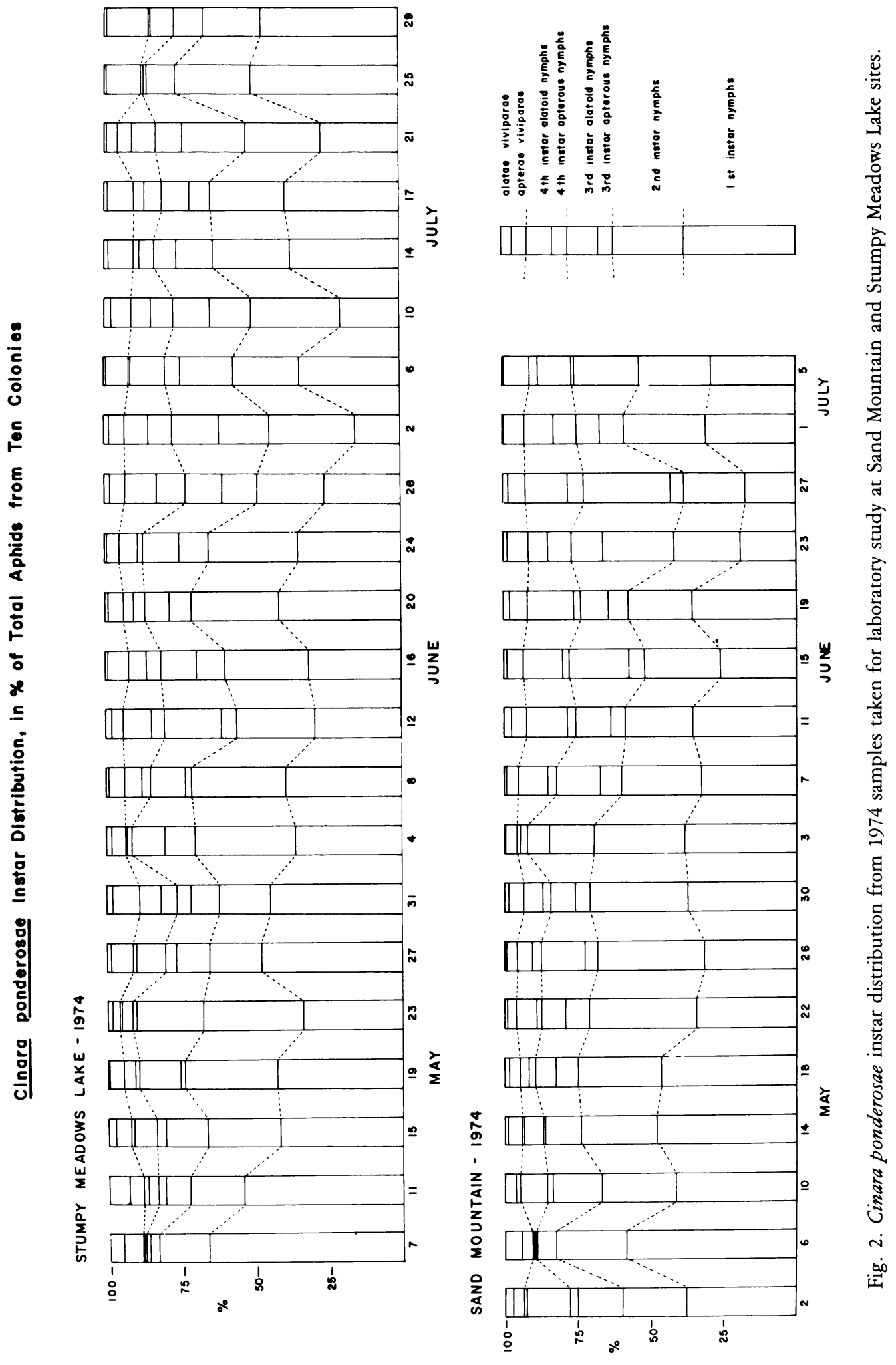




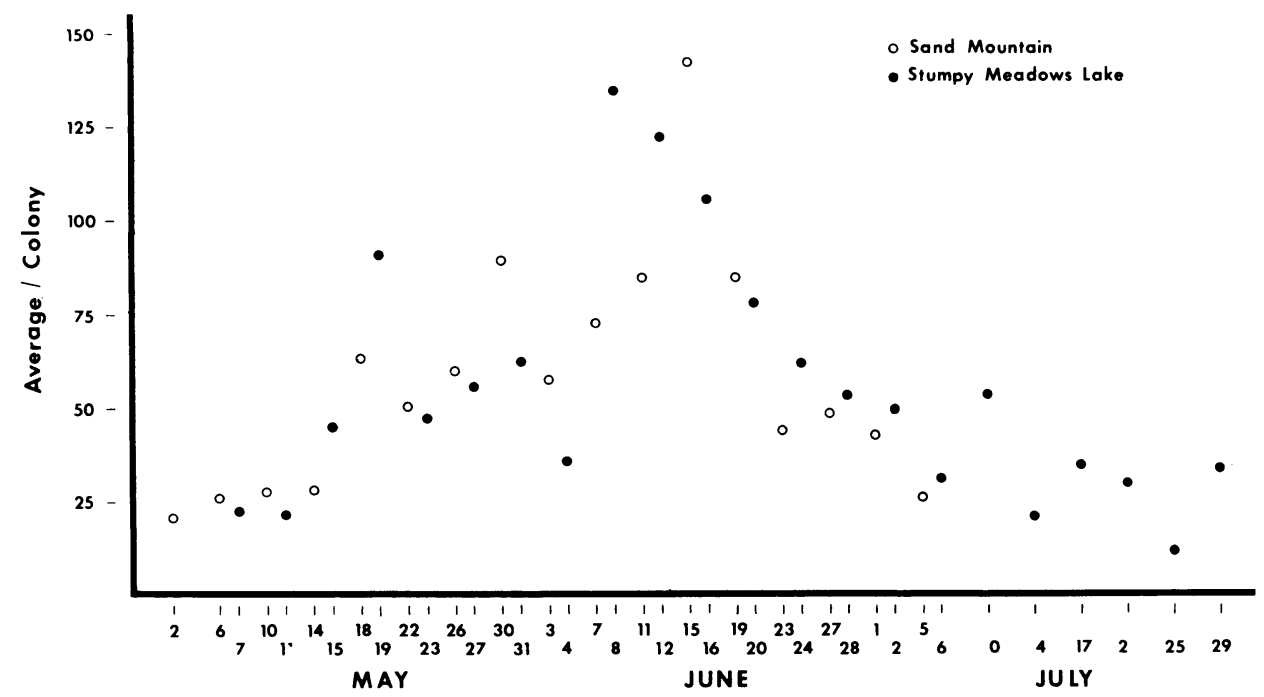

Fig. 3. Average number of $C$. ponderosae per colony for the Sand Mountain and Stumpy Meadows Lake sampling sites, 1974.

TABLE 1.

OBSERVED AND PREDICTED STABLE INSTAR DISTRIBUTIONS OF CINARA PONDEROSAE POPULATIONS ON PINUS PONDEROSAE AT STUMPY MEADOWS LAKE, 1974

\begin{tabular}{|c|c|c|c|c|c|c|c|c|}
\hline \multirow{3}{*}{$\begin{array}{l}\text { Sampling } \\
\text { date }\end{array}$} & \multicolumn{6}{|c|}{ Number of individuals/instar stage/sample ${ }^{*}$} & \multirow[b]{3}{*}{$\mathbf{e}^{\lambda}$} & \multirow[b]{3}{*}{$\mathbf{X}^{2 * *}$} \\
\hline & \multicolumn{3}{|c|}{ Observed } & \multicolumn{3}{|c|}{$\begin{array}{c}\text { Predicted } \\
\text { (first } 3 \text { instars) }\end{array}$} & & \\
\hline & 1st & 2nd & 3 rd & 1st & 2nd & $3 r d$ & & \\
\hline May 7 & 152 & 39 & 10 & 151 & 39 & 10 & 3.90 & 0.01 \\
\hline May 11 & 119 & 41 & 24 & 109 & 44 & 18 & 2.46 & 3.12 \\
\hline May 15 & 189 & 112 & 79 & 185 & 117 & 74 & 1.57 & 0.82 \\
\hline May 19 & 392 & 285 & 142 & 400 & 252 & 159 & 1.58 & 6.03 \\
\hline May 23 & 160 & 162 & 114 & 164 & 140 & 120 & 1.16 & 3.85 \\
\hline May 27 & 267 & 99 & 84 & 257 & 128 & 64 & 2.00 & 13.62 \\
\hline May 31 & 302 & 117 & 97 & 291 & 149 & 76 & 1.95 & 13.09 \\
\hline June 4 & 130 & 122 & 77 & 138 & 109 & 86 & 1.27 & 2.96 \\
\hline June 8 & 530 & 431 & 190 & 551 & 356 & 230 & 1.54 & 23.56 \\
\hline June 12 & 375 & 322 & 302 & 384 & 344 & 307 & 1.12 & 1.70 \\
\hline June 16 & 331 & 301 & 230 & 336 & 283 & 237 & 1.19 & 1.43 \\
\hline June 20 & 324 & 235 & 123 & 331 & 212 & 136 & 1.56 & 3.89 \\
\hline June 24 & 216 & 189 & 138 & 227 & 180 & 145 & 1.24 & 1.01 \\
\hline June 28 & 136 & 120 & 128 & 125 & 119 & 113 & 1.05 & 2.88 \\
\hline July 2 & 76 & 142 & 161 & 87 & 121 & 168 & 0.72 & 5.33 \\
\hline July 6 & 109 & 72 & 73 & 104 & 83 & 67 & 1.25 & 2.24 \\
\hline July 10 & 108 & 165 & 134 & 132 & 145 & 159 & 0.91 & 11.05 \\
\hline July 14 & 78 & 55 & 42 & 77 & 57 & 41 & 1.36 & 0.06 \\
\hline July 17 & 133 & 86 & 56 & 132 & 86 & 56 & 1.54 & 0.01 \\
\hline July 21 & 77 & 74 & 89 & 83 & 88 & 96 & 0.92 & 3.17 \\
\hline July 25 & 57 & 29 & 12 & 57 & 27 & 11 & 2.09 & 0.23 \\
\hline July 29 & 157 & 66 & 33 & 156 & 69 & 31 & 2.25 & 0.27 \\
\hline
\end{tabular}

"Each sample consisted of 10 colonies.

* * For values of $\mathrm{X}^{2}{ }_{\mathrm{df}}<3.84$ the observed instar distribution approximates a geometric progression. 


\section{Number of Colonies}

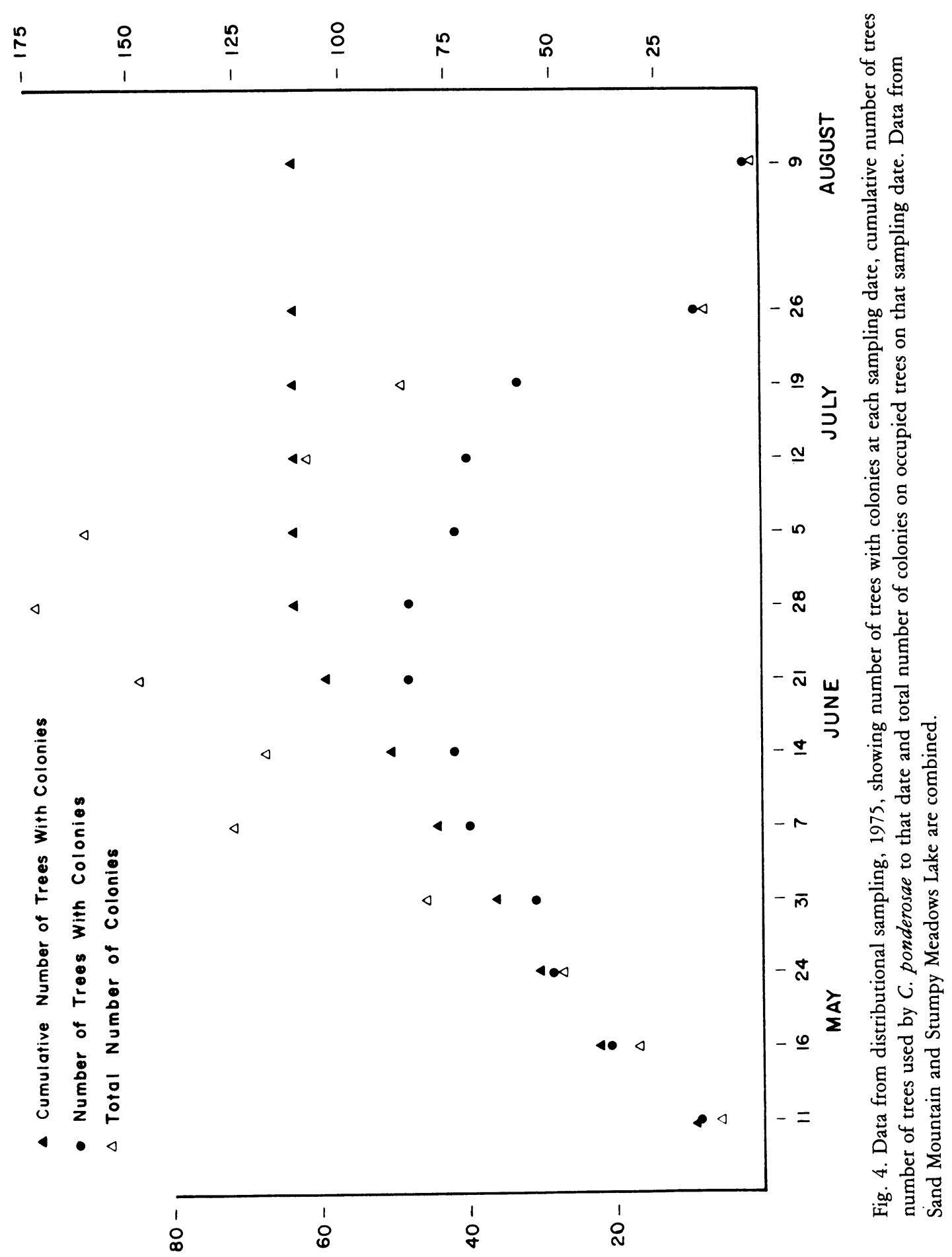

Number of Trees 
TABLE 2.

OBSERVED AND PREDICTED STABLE INSTAR DISTRIBUTIONS OF CINARA PONDEROSAE POPULATIONS ON PINUS PONDEROSAE AT SAND MT., 1974

\begin{tabular}{|c|c|c|c|c|c|c|c|c|}
\hline \multirow{3}{*}{$\begin{array}{l}\text { Sampling } \\
\text { date }\end{array}$} & \multicolumn{6}{|c|}{ Number of individuals/instar stage/sample * } & \multirow[b]{3}{*}{ e } & \multirow[b]{3}{*}{$\mathbf{X}^{2 \star *}$} \\
\hline & \multicolumn{3}{|c|}{ Observed } & \multicolumn{3}{|c|}{$\begin{array}{c}\text { Predicted } \\
\text { (first } 3 \text { instars) }\end{array}$} & & \\
\hline & $1 \mathrm{st}$ & 2nd & 3 rd & 1st & 2nd & 3rd & & \\
\hline May 2 & 79 & 47 & 38 & 77 & 52 & 35 & 1.48 & 0.79 \\
\hline May 6 & 151 & 62 & 18 & 152 & 57 & 21 & 2.66 & 0.87 \\
\hline May 10 & 114 & 70 & 51 & 112 & 74 & 48 & 1.52 & 0.44 \\
\hline May 14 & 131 & 71 & 35 & 132 & 70 & 36 & 1.91 & 0.05 \\
\hline May 18 & 293 & 180 & 93 & 296 & 171 & 99 & 1.73 & 0.87 \\
\hline May 22 & 173 & 183 & 82 & 189 & 141 & 105 & 1.34 & 18.90 \\
\hline May 26 & 187 & 215 & 115 & 208 & 171 & 140 & 1.22 & 17.91 \\
\hline May 30 & 335 & 301 & 120 & 359 & 238 & 157 & 1.51 & 27.00 \\
\hline June 3 & 220 & 178 & 130 & 220 & 171 & 132 & 1.29 & 0.32 \\
\hline June 7 & 237 & 202 & 163 & 236 & 195 & 163 & 1.20 & 0.26 \\
\hline June 11 & 307 & 201 & 145 & 307 & 209 & 142 & 1.47 & 0.37 \\
\hline June 15 & 370 & 367 & 367 & 371 & 370 & 368 & 1.00 & 0.03 \\
\hline June 19 & 304 & 192 & 139 & 303 & 202 & 135 & 1.50 & 0.62 \\
\hline June 23 & 85 & 101 & 159 & 78 & 110 & 153 & 0.72 & 1.60 \\
\hline June 27 & 86 & 102 & 169 & 75 & 108 & 156 & 0.69 & 3.03 \\
\hline July 1 & 133 & 123 & 71 & 140 & 106 & 80 & 1.32 & 4.09 \\
\hline July 5 & 74 & 64 & 60 & 71 & 64 & 57 & 1.11 & 0.28 \\
\hline
\end{tabular}

*Each sample consisted of 10 colonies.

* For values of $\mathrm{X}^{2}{ }_{1 \mathrm{df}}<3.84$ the observed instar distribution approximates a geometric progression.

TABLE 3

HETEROGENEITY CHI-SQUARE CALCULATIONS USING THE SAND MOUNTAIN AND STUMPY MEADOWS DATA GATHERED IN 1974 AND SHOWN ON TABLES 1 AND 2

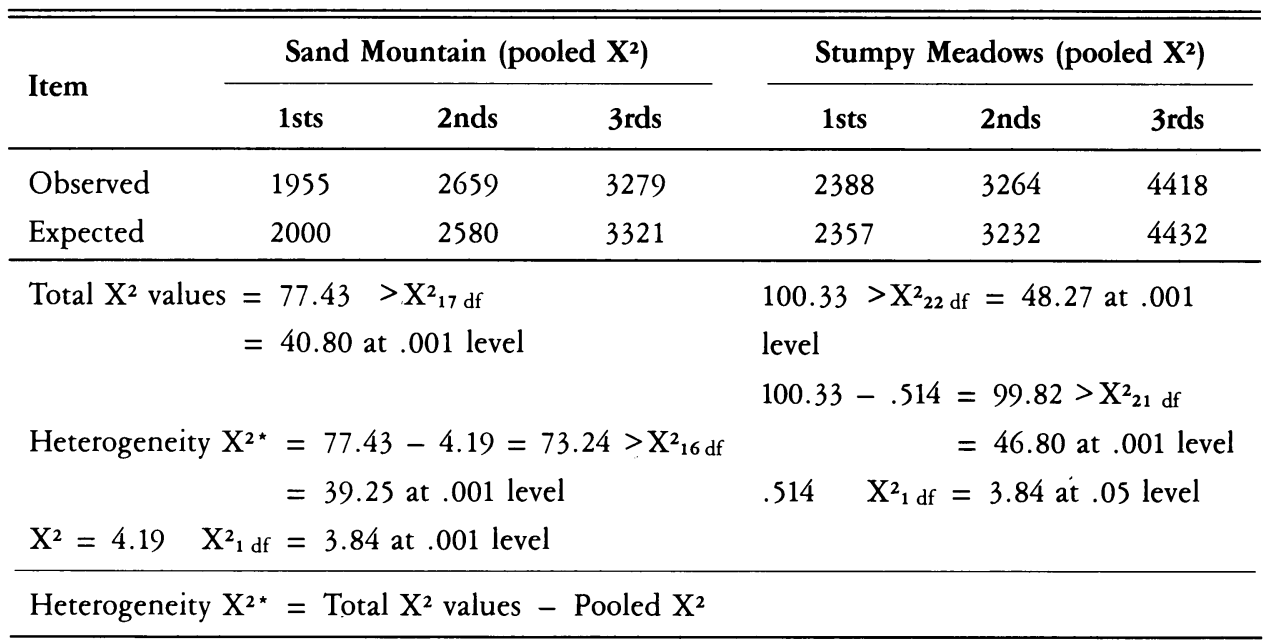

* Reject assumption that all samples are from a homogeneous population when Heterogeneity $\mathrm{X}^{2}$ greater than the maximum table values. 


\section{Life tables}

Life tables were developed from the 39 instar distributions shown in Figure 2. Life tables for three dates in the sampling program are shown in Figure 5. Instar distributions on these dates met the criteria outlined above for assuming a stable age distribution. Columns $\mathrm{A}$ and $\mathrm{D}$ are the total number of aphids sampled on the dates shown. Column $B$ is all of the aphids in Column A plus a predicted number of first instars. In B, losses of the various instars are indicated. These losses are assumed to have taken place before the next sampling date. Column $C$ is Column B minus the losses. In the transition from A to $B$, it was assumed that all of the 1sts from A became 2nds in B, and all the 2nds became 3rds, etc.

The first life table (Figure 5A) was based on the May 14 and 15 data and predicted May 18 and 19 . At this time of the year the population was growing very rapidly both in colony size and in number of colonies. Prediction in Column $\mathrm{C}$ was much smaller than that observed on May 18 and 19.

The second life table (Fig. 5B) was based on the June 11 and 12 data and predicted June 15 and 16. These dates coincided with maximum population size both in the number of colonies and numbers per colony. Prediction shown in Column $C$ is somewhat larger than the observation.

The third life table (Fig. 5C) was based on June 23 and 24 data and predicted June 27 and 28. This time period corresponded to the rapid decline in number of aphids per colony (Fig. 3), and the calculated value of $\mathrm{e} \lambda$ was less than one.

\section{In-situ observations and counts, 1974}

In situ observations and counts of aphids in premarked colonies provided clues as to the movement of aphids, especially later instars, to different areas on the tree. Close scrutiny with the hand lens required to make accurate counts in the field usually disturbed the aphids and caused them to run or drop off the trees. Counts of two colonies that remained in a fixed location are shown in Table 4. Older instars continually left the colony, a constant in all the colonies observed. In some cases, aphids were assumed to have joined one of the other colonies located in the tree. Colony Al-74-20 (Table 4) contained over 100 individuals, including a large number of 1st instars. In four days, despite thorough examination, not an aphid could be found on the entire tree. We had no explanation for this.

Parasitoids were often observed ovipositing in colonies, but few or no mummies were found in the colony or anywhere on the tree. Observations of parasitized individuals the following year showed that they left the tree completely; in one location, these parasitized individuals were found mummified on the trunk obscured under a thick layer of litter at the base of the tree. In another case, an entire ring of mummies was discovered around the trunk at ground level. We also noted that parasitized immigrant alatae remained in the colony until mummified.

\section{Distribution of $C$. ponderosae on host trees}

Figure 4 shows the number of trees with aphids for each date and the cumulative number of trees which had been used by $C$. ponderosae. Of the 100 trees, a maximum 


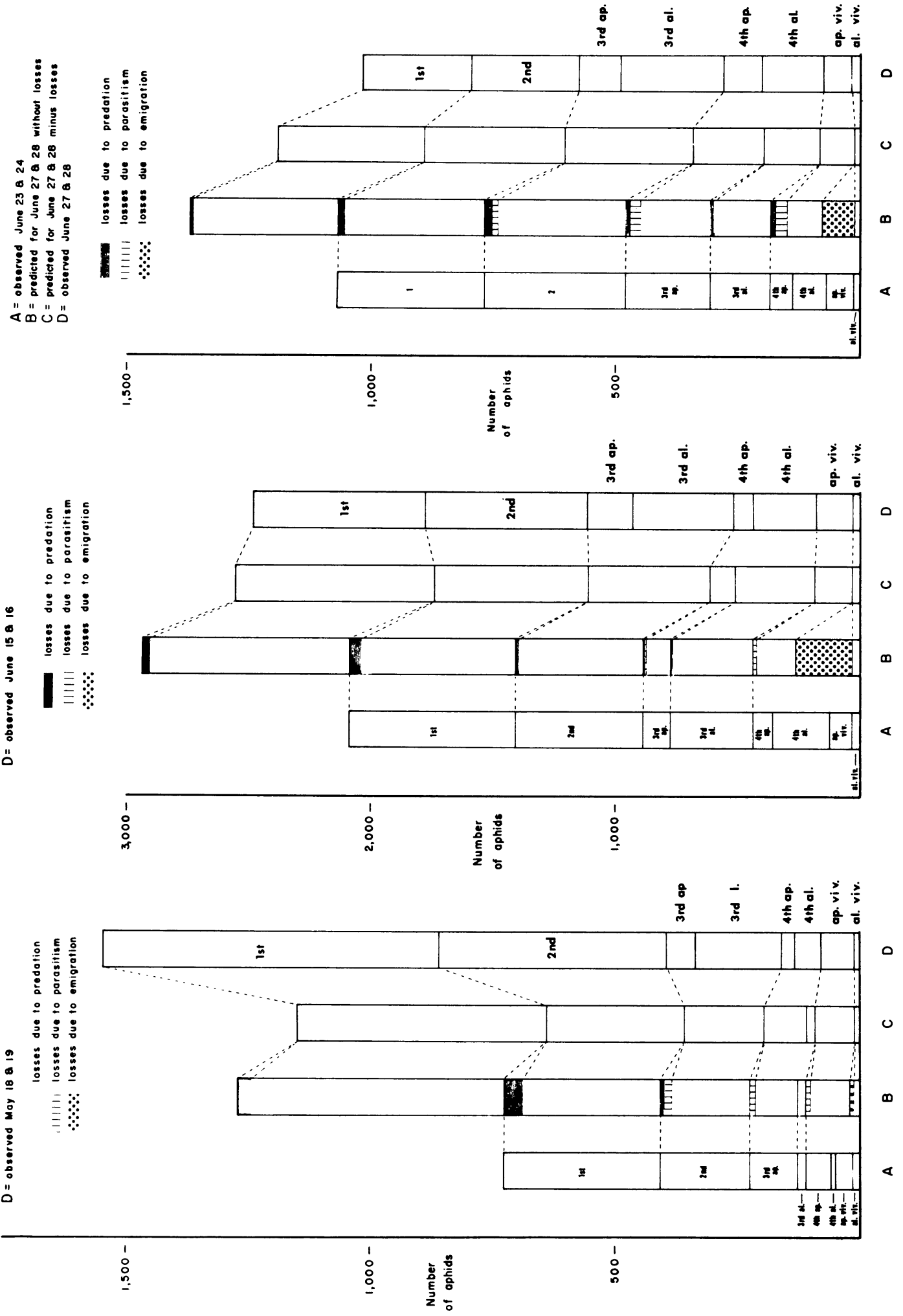

Fig. 5. Life tables constructed after Hughes (1972) from data gathered in destructive sampling, 1974. 
TABLE 4.

COUNTS OF CINARA PONDEROSAE AND ATTENDANT INSECTS * OBSERVED

IN TWO IN SITU COLONIES. SAND MOUNTAIN, 1974

\begin{tabular}{|c|c|c|c|c|c|c|c|c|c|c|c|}
\hline \multirow{3}{*}{$\begin{array}{l}\text { Collection } \\
\text { date }\end{array}$} & \multirow{3}{*}{$\begin{array}{l}\text { Total no. } \\
\text { aphids }\end{array}$} & \multicolumn{6}{|c|}{ C. ponderosae/instar stage $\Psi$} & \multirow{3}{*}{$\begin{array}{l}\text { ap. } \\
\text { viv. }\end{array}$} & \multirow{3}{*}{$\begin{array}{l}\text { al. } \\
\text { viv. }\end{array}$} & \multirow{3}{*}{ Parasitoids } & \multirow{3}{*}{ Predators } \\
\hline & & \multirow{2}{*}{ 1st } & \multirow{2}{*}{ 2nd } & \multicolumn{2}{|c|}{ 3rd } & \multicolumn{2}{|c|}{ 4th } & & & & \\
\hline & & & & ap. & al. & ap. & al. & & & & \\
\hline & & & & \multicolumn{8}{|c|}{ Colony Al-74-25 } \\
\hline May 1 & 12 & 3 & 6 & 0 & 0 & 0 & 0 & 0 & 3 & \multirow{9}{*}{ Pauesia, if } & \multirow{9}{*}{$\begin{array}{l}\text { syrphid, } \\
1 \mathrm{imm}, 2 \mathrm{e} \\
\text { Scymnus, } \\
1 \mathrm{imm} .\end{array}$} \\
\hline May 5 & 34 & 15 & 10 & 6 & 0 & 0 & 0 & 0 & 3 & & \\
\hline May 9 & 44 & 17 & 15 & 6 & 0 & 4 & 0 & 0 & 2 & & \\
\hline May 13 & 40 & 1 & 10 & 16 & 3 & 6 & 1 & 3 & 0 & & \\
\hline May 17 & 55 & 9 & 11 & 12 & 9 & 7 & 1 & 5 & 1 & & \\
\hline May 21 & 64 & 20 & 12 & 7 & 2 & 14 & 7 & 0 & 0 & & \\
\hline May 25 & 43 & 21 & 8 & 6 & 2 & 3 & 0 & 2 & 1 & & \\
\hline May 29 & 5 & 1 & 2 & 2 & 0 & 0 & 0 & 0 & 0 & & \\
\hline June 2 & 0 & 0 & 0 & 0 & 0 & 0 & 0 & 0 & 0 & & \\
\hline & & & & \multicolumn{8}{|c|}{ Colony A1-74-20 } \\
\hline April 30 & 14 & 6 & 6 & 0 & 0 & 0 & 0 & 0 & 2 & & \multirow{7}{*}{ syrphid, $3 \mathrm{e}$} \\
\hline May 5 & 30 & 6 & 11 & 11 & 0 & 0 & 0 & 0 & 2 & & \\
\hline May 9 & 40 & 9 & 9 & 10 & 0 & 9 & 0 & 0 & 3 & & \\
\hline May 13 & 36 & 5 & 13 & 7 & 0 & 9 & 0 & 1 & 1 & & \\
\hline May 17 & 35 & 16 & 9 & 3 & 0 & 2 & 0 & 4 & 1 & & \\
\hline May 21 & 65 & 37 & 10 & 12 & 0 & 3 & 2 & 0 & 1 & & \\
\hline May 25 & 0 & 0 & 0 & 0 & 0 & 0 & 0 & 0 & 0 & & \\
\hline
\end{tabular}

* $T$. sessile was the ant species attending colonies at all times.

I ap = apterous, al = alatoid, ap.viv. = apterous vivparae, al.viv. = alate vivparae

of 48 aphids on them at one time, and 62 were used at one time or another throughout May, June, and July. The last time a new tree was occupied (June 28) was just before the dates in 1974 when colony size was at a maximum (Fig. 3). This also corresponded to the maximum number of colonies per tree (Fig. 6) and the maximum cumulative number of colonies on all trees combined (Fig. 4). The tree maps (Figs. 7 and 8) show the movement of aphids and the establishment of new colonies at other points on the tree. Tree 58 (Fig. 7) had its first colony on whorl IV and when first seen had an alate and nymphs. On May 31, the alate was not to be found, and the remaining aphids had moved to the tip of the tree. On June 7, or during the previous week, another alate arrived on the tree and during the following week two more alatae arrived. This tree was colonized by four separate alatae. Tree 2 (Fig. 8) showed a similar pattern. On June 7 two alatae were recorded; none were found on May 31. In both examples the original colony location was occupied for less than 3 weeks, supporting observations made of marked colonies the previous year. The phenomenon was observed many times: several migrants colonizing one tree, while many other small ponderosa pines available in close proximity had no aphids on them.

Although 62 percent of the potential host trees were occupied, the majority of the usable locations on any tree did not have aphid colonies on them. At the maximum infestation levels observed in this study, $C$. ponderosae did not seem to be limited by its food resource. 


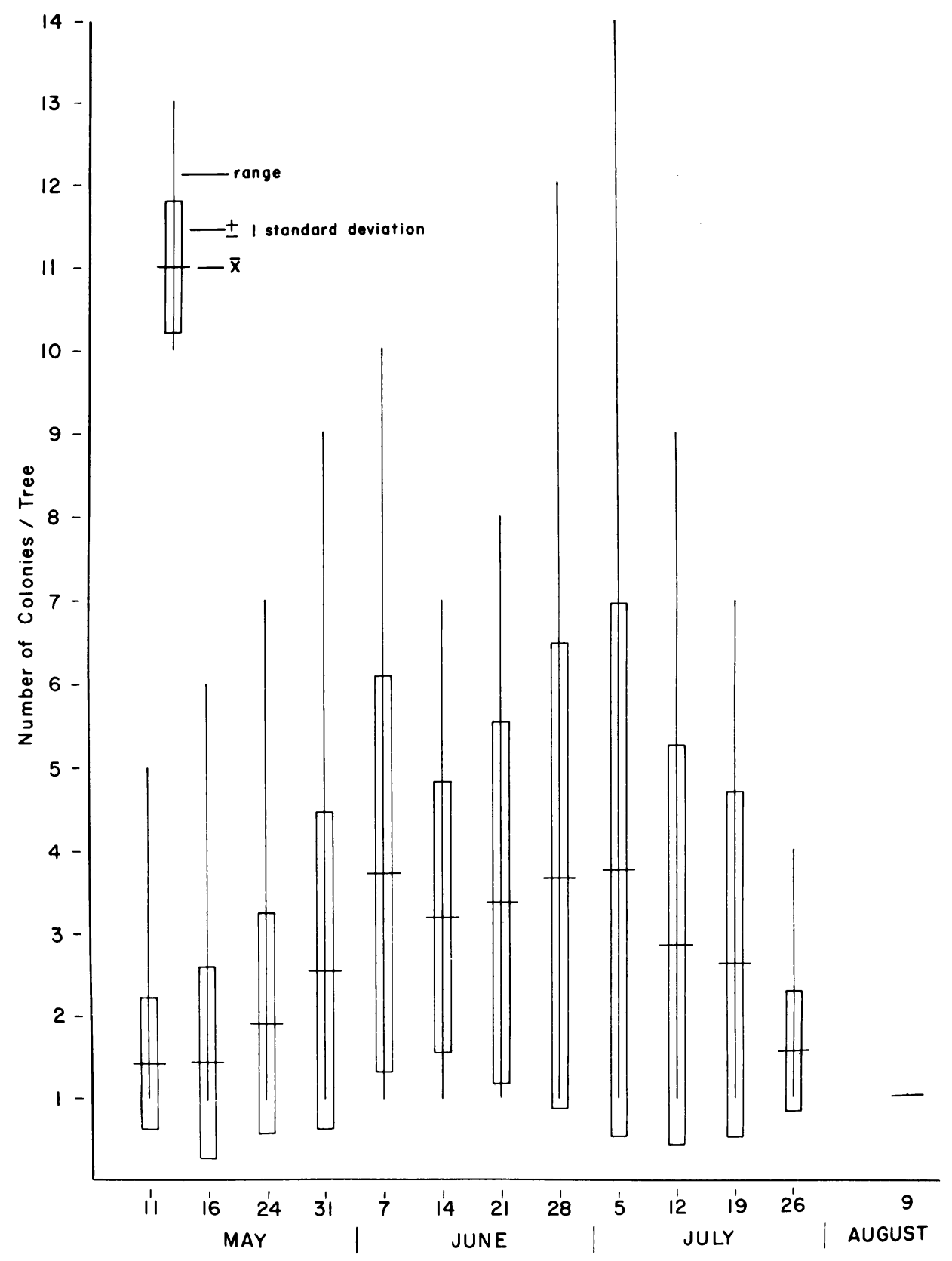

Fig. 6. Number of colonies per tree as observed in the distributional sampling, 1975. Data combined from both Sand Mountain and Stumpy Meadows Lake. 


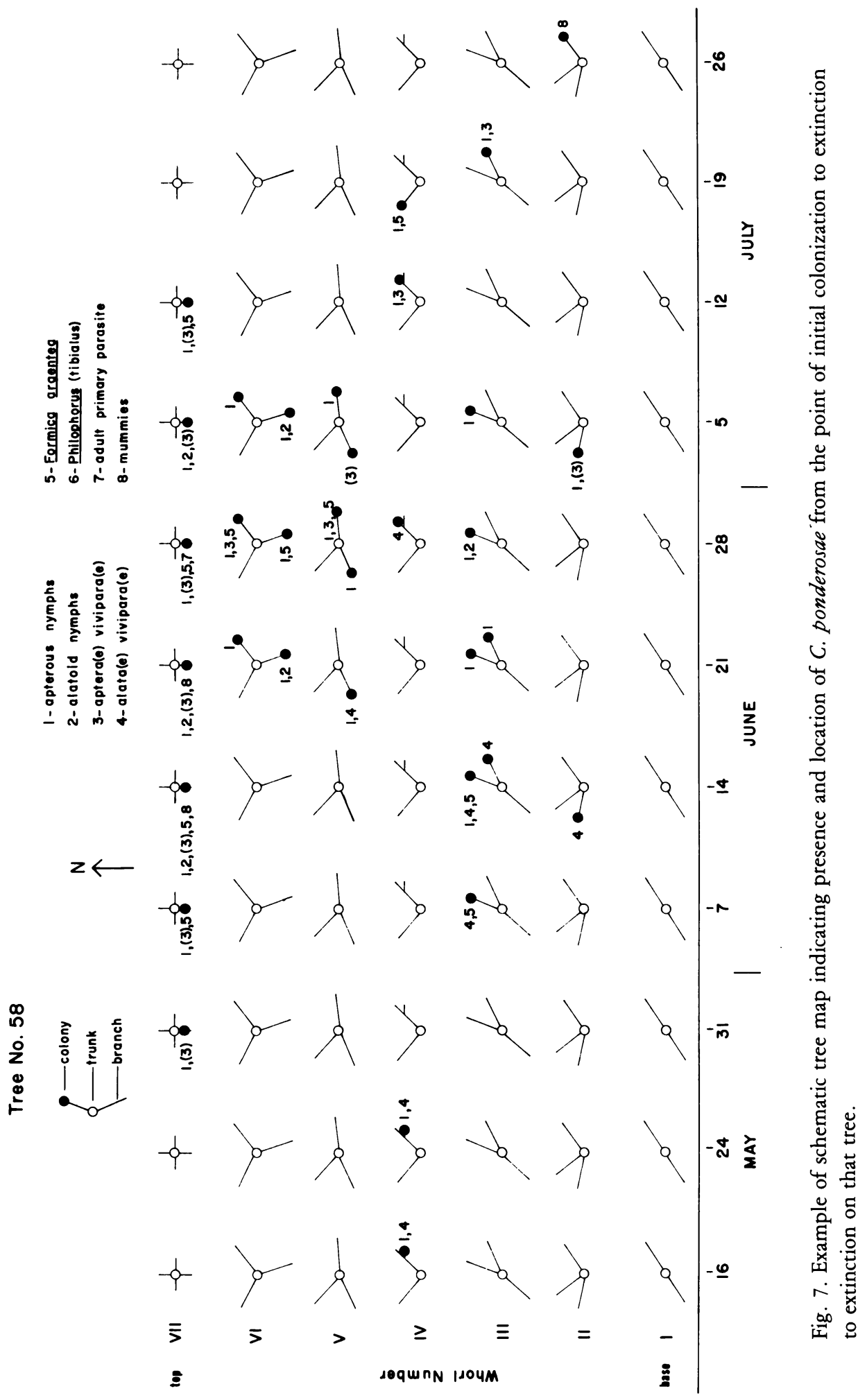




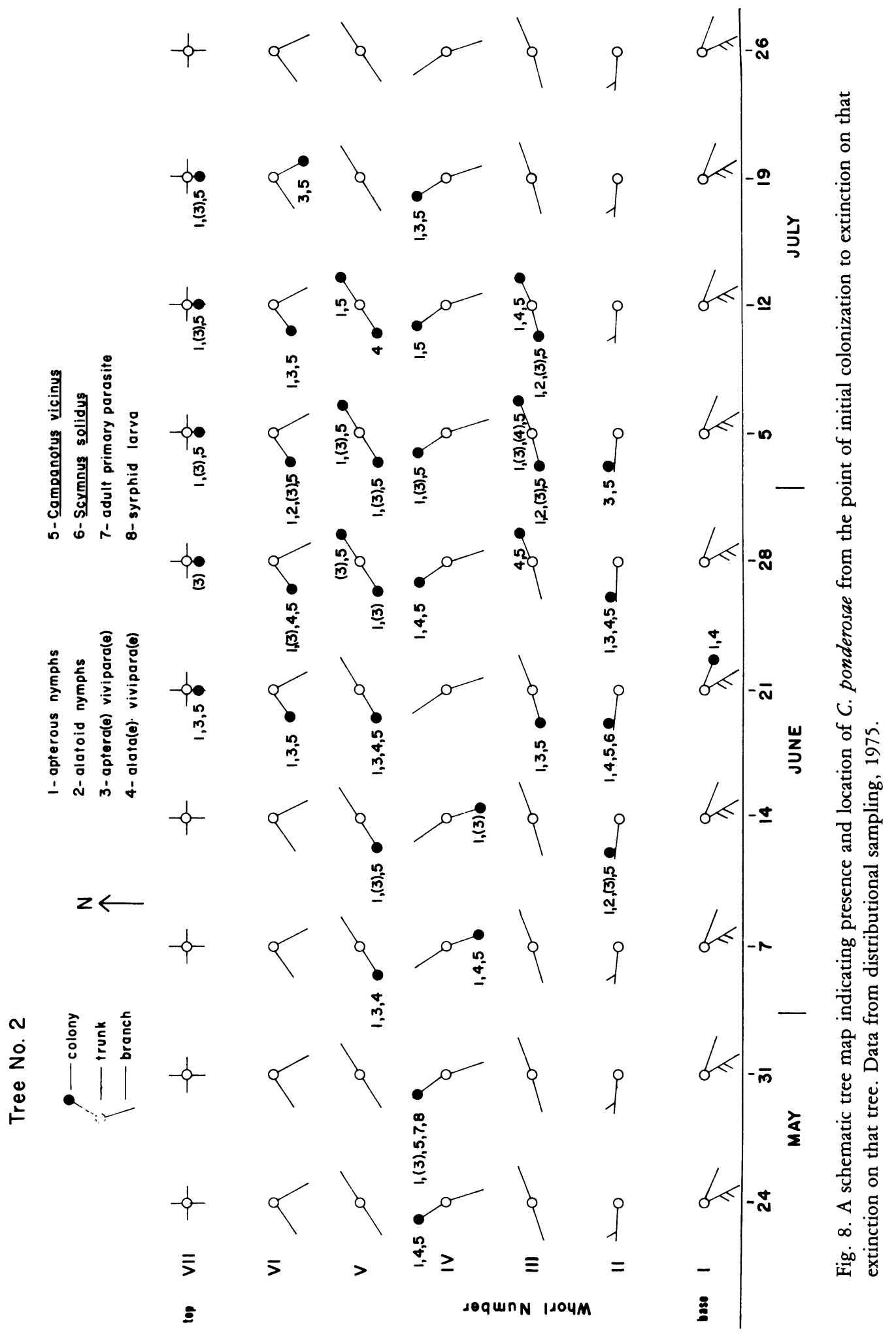




\section{Associated insects}

Ants. Seven species of ants, Camponotus modoc Wheeler, C. vicinus Mayr, Formica argentea Wheeler, $F$. nevadensis Wheeler, F. sp., Liometopum occidentale Emery and Tapinoma sessile (Say) were observed attending $C$. ponderosae colonies in the study area. Cinara ponderosae did not seem to be as attractive to ants as were other cinaran species. About half of the colonies had no ants present. The relatively small number of aphids in these colonies may have reduced their attractiveness to ants. On the other hand, some of the larger colonies of $C$. ponderosae and other Cinara spp. had so many ants in attendance that aphids were scarcely visible.

All the above ant species varied in their behavior in the presence of aphid colonies. Tapinoma sessile leaves the colony when disturbed. Camponotus vicinus, $C$. modoc and Formica argentea are moderately aggressive against adult predators. Formica nevadensis, F. sp. and Liometopum occidentalis are very aggressive, and fewer predator larvae were collected with colonies attended by these species. None of the species were able to prevent parasitoids from gaining access to the colony although the ants' rapid movement was observed to interfere with the parasitoids enough to make them leave the colony. Individuals of $F$. nevadensis were observed palpating adult parasitoids with their antennae while the parasitoids were ovipositing, but no aggressive behavior was exhibited.

\section{Parasitoids}

Four primary parasitoids were reared from C. ponderosae mummies: Xenostigmus bifasciatus (Ashmead), Pauesia laricis (Haliday), P. ponderosae Muesebeck and $P$. sp. The genus Pauesia is mainly limited to Cinara spp., and Xenostigmus to the Lachninae (Mackauer and Stary, 1967). Two secondary parasitoids, Euneura lachni (Ashmead) and

TABLE 5

PRIMARY AND SECONDARY PARASITOIDS EMERGED FROM MUMMIES OF CINARA PONDEROSAE COLLECTED WITH AND REARED FROM LIVE APHIDS IN THE COLONIES TAKEN TO THE LABORATORY, 1974

\begin{tabular}{lccccc} 
& \multicolumn{5}{c}{ Species } \\
\cline { 2 - 4 } $\begin{array}{l}\text { Source of } \\
\text { mummies }\end{array}$ & Alloxysta & Euneura & $\begin{array}{c}\text { Xenostigmus } \text { and } \\
\text { Pauesia spp. }\end{array}$ & $\begin{array}{c}\text { No } \\
\text { emergence }\end{array}$ \\
\cline { 4 - 5 } & 2 & 61 & 6 & 18 & 13 \\
$\begin{array}{l}\text { Stumpy Meadows Lake: } \\
\text { Taken with colonies }\end{array}$ & 39 & 0 & 153 & 258 & 59 \\
$\begin{array}{l}\text { Developed } \\
\text { in petri dishes }\end{array}$ & 3 & 37 & 11 & 24 & 24 \\
$\begin{array}{l}\text { Sand Mountain: } \\
\text { Taken with colonies }\end{array}$ & 56 & 2 & 90 & 172 & 30 \\
$\begin{array}{l}\text { Developed } \\
\text { in petri dishes }\end{array}$ & & & & & \\
\hline
\end{tabular}


Alloxysta lachni (Ashmead) were also reared. Fewer mummies were taken with the colonies than were reared from the aphids in the laboratory (Table 5). This supports observations in situ that parasitized aphids do not generally remain in the colony (also documented by Scheurer, 1964). Movement of parasitized individuals out of the colony and even off of the host plant would serve to remove the parsitoid from other potential hosts (of benefit to the aphid population). Removal would also prevent predation on the aphid before mummification; it may also reduce exposure of the parasitoid to secondary parasitoids.

No teneral alatae and very few alatoid nymphs mummified. Some mechanism may prevent parasitoid egg hatch until the alatae have flown and begun to feed. We observed no discrimination between alatoid and apterous nymphs in ovipositing primary parasitoids.

\section{Predators}

The following predators were found feeding on $C$. ponderosae in the westside Sierra Nevada: Syrphidae: Eupeodes volucris O.S., Metasyrphus lapponicus (Zett.) Metasyrphus (s.s.) sp., Scaeva pyrastri (L.); Chamaemyiidae: Leucopis americana Malloch; Coccinellidae: Scymnus solidus Casey and Hippodamia convergens Guerin; Miridae: Deraeocoris ingens Van Duzee, Philophorus sp., and Dacerla sp.; Neuroptera: Chrysopa carnea Stephens and Hemerobius kokeneeanus Currie; Araneae: Phidippus johnsoni Peckham, Metaphidippus sp., and Linyphia sp.; Acarina: Allothrombium (s.l.) sp.

Bradley and Hinks (1968) considered the omnipresent spiders (not counted in this study) to be major predators of cinarans, although they rarely observed spiders feeding on aphids. We observed webs of the dome-forming spiders, Linyphiidae, with alatae caught on the underside of the dome. Predators other than those observed undoubtedly occur.

Larval Scymnus solidus was the most common predator collected; they feed by biting an appendage and sucking the body fluids.

Hippodamia convergens migrate to the Sierra Nevada in the late spring and form aggregations (Hagen, 1962). At this time they have been observed to decimate $C$. ponderosae populations near an aggregation site.

The predatory mirid, Deraeocoris ingens, is very common on small ponderosa pines during the late spring. They are fast, adept at avoiding ants, and equally adept at preying on aphids, which they can carry on the end of their rostrum as they feed.

Syrphid larvae were not abundant, and none were collected with colonies later than the end of June. Laboratory-fed larvae of Scaeva pyrastri and Eupeodes volucrus consumed 40 to $503 \mathrm{rd}$ and 4 th instars of $C$. ponderosae from hatch to pupation. Small colonies were observed to be completely decimated by syrphid larvae.

Chamaemyiid larvae, Leucopis americana, are so small that they act like ectoparasites riding on the dorsum of the aphids while they feed. Rearing records indicated they will mature after feeding on two of each nymphal instar of $C$. ponderosae. 


\section{DISCUSSION}

\section{Sampling}

The technique for taking samples to study in the laboratory (destructive sampling) was designed by the senior author during the summer of 1973 after personal observations of the local $C$. ponderosae population. The large number of ponderosa pines in both sampling areas made it possible to take colonies from a different set of trees each sampling period, until near the end of July, when it was necessary to search the entire area to find 10 colonies. The decision to take the first colony observed was to eliminate bias in selecting among the several colonies that may have been present on the tree. In the previous season, we also observed that when several colonies were located on a tree, instar distribution was much the same among them. Thus, samples were taken from 10 different trees each sampling date; each tree, in all probability, had been colonized at a different time (Fig. 4).

\section{Life tables}

Although Hughes's $(1962,1972)$ time-specific life tables and the underlying assumptions have been criticized (Carter, et al, 1978), the method can still be useful for examining sequential samples such as were gathered during this study. .(See the three graphical life-table representations in Fig. 5).

In the early spring observation (May 14 and 15) (Fig. 5A), the estimated population is far less than that observed 4 days later. Most likely, one instar period during this time of the year is less than the 4-day interval between samplings. Observations in the spring of 1975 show that instar periods could be as short as 2.5 days, which would cause the observed numbers to be much larger than predicted numbers.

In early June (Fig. 5B) the predictions were larger but close to observed numbers. This suggests that one instar period may have been longer at this time, that is, approximately equal to the 4-day sampling interval. Possibly, some mortality factor was underestimated.

In Figure 5C, an e $\lambda$ value of less than one suggests a significant loss of 1st instars or a reduction in the number of producing adults. The latter is more likely, because the majority of the potential adults were altoid and did not remain in the area. It seems likely that some mortality factor was overlooked or underestimated for this period, because the observed numbers were considerably less than in the prediction column. At this time most of the predation must be done by adult predators, because few larvae were found in the colonies.

\section{Annual cycle of $C$. ponderosae}

The annual cycle for $C$. ponderosae may be summarized as follows:

November to March. - Colonies can be found on small ponderosa pine at its lowest elevation in the foothills of the Sierra Nevada.

April to June. - Alatae migrate up the west slope of the Sierra Nevada. The advancing edge of this migration is closely correlated with bud burst in ponderosa pine. Upper elevations $(1,800$ to $2,000 \mathrm{~m})$ are reached by mid June. 
July to August. - Continual migration of the third generation occurs throughout the area. Colonies become increasingly scarce during this period. Those colonies which survive are usually large and well attended by ants.

September to December.-Colonies that survive the late summer will remain on host trees at the upper elevations, until the severe weather kills them.

We have observed that this annual pattern is different from those of other cinarans in the same area. The most obvious difference is anholocycly which one might expect in the milder climatic areas of California, such as the Coast Range, but hardly in the Sierra Nevada, where winter weather can be very severe. This species forms sexuales in the Rocky Mountain Region (Palmer, et al. 1926), so anholocycly must be an adaptation to the climatic conditions of California.

Certain advantages could be proposed for evolving complete anholocyclic populations in areas with a mild climate. Sexuale production would be an unnecessary expenditure of energy, if they are unnecessary for survival. The number of males produced reduces the number of reproducing forms, and the oviparae produce fewer eggs than the viviparae produce live nymphs by at least one-third (Scheuer, 1964). Another advantage would be the possibility of utilizing lower temperatures, below the threshold at which natural enemies function, for feeding and reproduction. Predators and parasites of aphids generally have higher developmental thresholds than their host aphids (Bodenheimer and Swirski, 1957; Neuenschwander, Hagen, and Smith, 1975). The aphid is at an advantage during the colder parts of the year, depending on the magnitude of the difference between the two thresholds and providing its own host plant is available. Indications are that Cinara ponderosae appears to withstand low temperature, and its population appears to suffer minimal predatory interference throughout late fall, winter, and early spring. Birds, such as the mountain chickadee (Parus gambeli), that exhibit bark-gleaning behavior take aphids during the winter months (Dahlsten and Copper, 1979) and could cause significant losses. The consequences of growth during lower temperatures would be the availability of a large number of alate viviparae for the migration and colonization of the west slope of the Sierra Nevada every spring.

The local population of Cinara ponderosae is also different from other cinarans. Colonies rarely get very large and are continually moving on the host tree. Almost all of the third generation emigrates, which may minimize the impact of natural enemies, because the aphids do not seem to be very well protected by ants. Losses sustained by the migratory alatae are impossible to quantify, but the difficulty of locating new colonies started by alatae after mid July suggests that mortality must be extremely high.

Samples gathered for the construction of life tables indicate that predator and parasitoid mortality is comparatively low. It becomes a factor in reducing or decimating a local population only after a majority of the third aphid generation has emigrated. 


\section{ACKNOWLEDGMENT}

We would like to thank Herbert Baker, George Carroll and Larry Pike for review of the manuscript. The following confirmed species mentioned in this paper; Ching-Shen Liu, J. R. Vockeroth, K. S. Hagen, T. P. Sluss, S. Szerlip, C. E. Griswald, P. Neuenschwander, I. Newell, Z. Boucek, F. Andrews, and R. Snelling.

The map of California was used with permission of the California Insect Survey, Department of Entomology, University of California, Berkeley. We are grateful also for the assistance of the late Herbert C. Sampert, forest manager, Blodgett Experimental Forest.

Portions of this work were supported by National Science Foundation Training Grant GZ1373.

\section{LITERATURE CITED}

BODENHEIMER, F. S., AND E. SWIRSKI

1957. The Aphidoidea of the Middle East. Weizmann, Jerusalem. 378 pp.

BRADLEY, G. A., and J. D. HINKS

1968. Ants, aphids and jack pine in Manitoba. Can. Entomol. 100:40-50.

CARTER, N., D. P. AIKMAN, and A. F. G. DIXON

1978. An appraisal of Hughes' time specific life analysis for determining aphid reproductive and mortality rates. J. Anim. Ecol. 47: 677-87.

DAHLSTEN, D. L., AND W. A. COPPER

1979. The use of nesting boxes to study the biology of the mountain chickadee (Parus gambeli) and its impact on selected forest insects. Pp. 217-260 In: J. G. Dickson, R. W. Connor, R. R. Fleet, J. A. Jackson and J. C. Kroll, Editors, The Role of Insectivorous Birds in Forest Ecosystems. Academic Press, New York. 381 pp.

HUGHES, R. D

1962. A method for estimating the effects of mortality on aphid populations. J. Anim. Ecol. 31: 389-96. HUGHES, R. D.

1972. Population Dynamics. In: H. F. Van Emden, Editor. Aphid Technology. Academic Press, London and New York. $344 \mathrm{pp}$.

JOHNSON, N. E.

1965. Reduced growth associated with infestations of Douglas-fir seedlings by Cinara species (Homoptera: Aphididae). Can. Entomol. 97: 113-19.

MACKAUER, $M$. and P. STARY

1967. Index of World Aphidiidae. In Index to Entomophagous Insects. Editors: V. Delucchi and G. Remaudiere. Paris: Le Francois. 195 pp.

NEUENSCHWANDER, P., K. S. HAGEN, and R. F. SMITH

1975. Predation on aphids in California alfalfa fields. Hilgardia 43: 53-78.

PALMER, M. A.

1926. Life history studies of seven described species of the genus Lachnus. Annals Entomol. Soc. Amer. 19: $300-30$.

SCHEURER, $S$.

1964. Untersuchungen sum Massenwechsel einiger Fichten bewohnender Lachnidenarten im Harz. Biol. Sentralbl. 83: 427-467. 
